\section{Effect of Mulch Type and Depth on Rooting of Stem Cuttings and Weed Control in Containers}

\author{
Isha Poudel ${ }^{1}$ and Anthony L. Witcher ${ }^{1}$
}

AdDitional Index words. Buddleja davidii, butterfly bush, Cardamine hirsuta, crape myrtle, creeping woodsorrel, Digitaria sanguinalis, Fatoua villosa, hairy bittercress, hydrangea, Hydrangea paniculata, Lagerstroemia indica, large crabgrass, mulberry weed, Oxalis corniculata, propagation

SUMMARY. Weeds are a major problem in cutting propagation and compete with the main crop for water, sunlight, and nutrients, thus reducing growth and marketable quality of rooted cuttings. Due to the high labor cost of hand weeding, mulches can be an alternative method for weed control in the propagation environment. The objective of this research was to determine the effect of mulches (coarse vermiculite, rice hulls, paper pellets, and pine pellets) on rooting of stem cuttings and weed control when applied at 0.5 - and 1 -inch depths. Cuttings of three plant species ['Nanho Blue' butterfly bush (Buddleja davidii), 'Catawba' crape myrtle (Lagerstroemia indica), 'Phantom' hydrangea (Hydrangea paniculata)] were stuck in 2.5-inch-diameter containers filled with pine bark substrate and treated with mulch. In a separate study, seeds of four weed species [creeping woodsorrel (Oxalis corniculata), hairy bittercress (Cardamine hirsuta), large crabgrass (Digitaria sanguinalis), mulberry weed (Fatoua villosa)] were sown onto the mulch surface. Rooting percentage was unaffected by mulch type or depth for any of the three crop species ('Nanho Blue' butterfly bush, 'Catawba' crape myrtle, 'Phantom' hydrangea). Pine pellets did not affect root dry weight of any crop species, but root length and volume of 'Catawba' crape myrtle was reduced by pine pellets at 1 -inch depth. Rice hulls slightly reduced the root length and volume of 'Catawba' crape myrtle, but the reduction was less than $50 \%$. Pine pellets and paper pellets (both depths) reduced growth of all four weed species. Even though weed seeds germinated in pine and paper pellets, seedlings did not grow large enough to potentially affect crop rooting. In conclusion, pine pellets and paper pellets at 0.5 -inch depth can be effective in suppressing weed populations with minimal effect on rooting.

W eeds are a major problem in cutting propagation, but management is difficult due to lack of viable control methods. Weed control in propagation is commonly addressed by manual removal (hand weeding), which is time-consuming and labor-intensive. Recently, there has been a decrease in availability of agricultural labor supply, which places a strain on growers, and common tasks such as hand weeding may

Received for publication 21 Sept. 2021. Accepted for publication 13 Dec. 2021

Published online 8 February 2022

${ }^{1}$ Tennessee State University, Otis L. Floyd Nursery Research Center, McMinnville, TN 37110

This research was supported by the National Institute of Food and Agriculture, U.S. Department of Agriculture Evans-Allen grant under award number TENX-1925-CCOCP.

A.L.W. is the corresponding author. E-mail: awitcher@tnstate.edu.

This is an open access article distributed under the CC BY-NC-ND license (https://creativecommons. org/licenses/by-nc-nd/4.0/).

https://doi.org/10.21273/HORTTECH04937-21 be performed less frequently (Charlton and Taylor, 2016). As a result, weed infestations during propagation result in lower quality rooted cuttings, transfer of weed populations to general production areas, and delayed finishing times due to competition for light, space, and nutrients. Although hand weeding must be performed to remove existing weeds, growers need costeffective methods for preventing weed establishment during propagation.

Although preemergence herbicides are a cost-effective method for controlling weeds during crop production, there are several limitations for using preemergence herbicides during propagation. Currently, there are no preemergence herbicides labeled for use on nonrooted cuttings (Cochran et al., 2008; Cook and Neal, 2001; Judge et al., 2004; Marble and Chandler, 2016). Also, there is limited research on determining the herbicide safety and its actions during propagation and root development (Thetford and Gilliam, 1991). Furthermore, no preemergence herbicides are labeled for use on crops inside enclosed structures such as a greenhouse. Because most propagation is conducted inside enclosed structures, use of preemergence herbicides is not recommended (Altland et al., 2003). Preemergence herbicides are restricted for use in enclosed structures due to possible volatilization and codistillation of the herbicide and subsequent plant injury (Cochran et al., 2008).

Mulches have been identified as an alternative to preemergence herbicides to control weeds in container-grown crops. During crop production in containers, mulches are applied to the substrate surface to create a physical barrier, which will inhibit weed seed germination and suppress weed growth (Ferguson et al., 2008). Although mulches have not been widely adopted in container production, researchers have suggested several mulches for their ability to control weeds (Abbey et al., 2001; Mathers and Ozkan, 2001). In a study by Bartley et al. (2017), wood mulches derived from eastern red cedar (Juniperus virginiana), ground whole loblolly pine (Pinus taeda), chinese privet (Ligustrum sinense), and sweetgum (Liquidambar styraciflua) applied at 1 -inch depth reduced fresh weight of weed biomass by $82 \%$ to $100 \% 1$ month after sowing. Parboiled rice (Oryza sativa) hulls are commercially available and are

\begin{tabular}{llll}
\hline $\begin{array}{l}\text { Units } \\
\text { To convert U.S. to SI, } \\
\text { multiply by }\end{array}$ & U.S. unit & SI unit & $\begin{array}{l}\text { To convert SI to U.S., } \\
\text { multiply by }\end{array}$ \\
\hline 29.5735 & fl oz & $\mathrm{mL}$ & 0.0338 \\
2.54 & inch $(\mathrm{es})$ & $\mathrm{cm}$ & 0.3937 \\
25.4 & inch $(\mathrm{es})$ & $\mathrm{mm}$ & 0.0394 \\
16.3871 & inch & $\mathrm{cm}^{3}$ & 0.0610 \\
0.5933 & $\mathrm{lb} / \mathrm{yard}^{3}$ & $\mathrm{~kg} \cdot \mathrm{m}^{-3}$ & 1.6856 \\
28.3495 & $\mathrm{oz}$ & $\mathrm{g}$ & 0.0353 \\
1 & $\mathrm{ppm}$ & $\mathrm{mg} \cdot \mathrm{L}^{-1}$ & 1 \\
$\left({ }^{\circ} \mathrm{F}-32\right) \div 1.8$ & ${ }^{\circ} \mathrm{F}$ & ${ }^{\circ} \mathrm{C}$ & $\left({ }^{\circ} \mathrm{C} \times 1.8\right)+32$ \\
& & &
\end{tabular}


used for weed control on containergrown crops inside greenhouses and on crop species sensitive to preemergence herbicides (Altland et al., 2016). Altland and Krause (2014) reported rice hull mulch at a depth of 1 inch provided excellent control of flexuous bittercress (Cardamine flexuosa) and liverwort (Marchantia polymorpha) when seeds were disseminated onto the mulch surface. Other mulch products were also found to be effective in reducing weeds in containers including weed discs and plastic bags (Chong, 2003). Smith et al. (1998) reported that recycled wastepaper pellets applied to a depth of 1 inch reduced prostrate spurge (Chamaesyce maculata) seedling number and fresh weight compared with non-treated containers and could reduce herbicide use while decreasing time and labor required for hand weeding.

With limited options for weed control in propagation, mulches can be a viable alternative for growers; however, there are some potential challenges for using mulches in cutting propagation. Most cutting propagation is performed in small diameter containers, precluding the use of mulches with a large particle size such as pine (Pinus sp.) bark nuggets and most other wood-derived materials. Mulches with a small particle size, such as rice hulls and recycled paper pellets, may be more appropriate for use in small containers. Weed control efficacy is critical to selecting a mulch, but other factors such as application depth and chemical properties should be considered to ensure there are no negative effects on root development. Reports of mulch use in nursery container production have shown similar or increased plant growth compared with nonmulched plants (Marble et al., 2019). Few studies have evaluated mulches in propagation, but Witcher and Poudel (2020) reported several mulches (pine pellets, paper pellets, and rice hulls) had no effect on rooting of cuttings when applied at 0.3 -inch depth. In the same study, mulches varied in weed control efficacy among weed species, but reduced growth of hairy bittercress (pine pellets) and creeping woodsorrel (paper pellets) was observed.

On the basis of reports of mulches used in container-grown crops and limited reports of use in propagation, a mulch depth of at least 0.5 inch must be used for adequate weed control. We have identified several mulches that may be viable for use in cutting propagation. Therefore, the objective of this study was to determine the effect of mulch type and depth on rooting percentage, root growth, and weed control efficacy during stem cutting propagation of select ornamental species.

\section{Material and methods}

Experiments were conducted in 2020 at the Tennessee State University Otis L. Floyd Nursery Research Center in McMinnville (lat. $35.7102174^{\circ} \mathrm{N}$, long. $85.7904774^{\circ} \mathrm{W}$ ).

Rooting. Two node terminal and subterminal stem cuttings of three plant species ['Nanho Blue' butterfly bush (Buddleja davidii), 'Catawba' crape myrtle (Lagerstroemia indica), and 'Phantom' hydrangea (Hydrangea paniculata)] were collected 19 May 2020 from container-grown stock plants. Standard procedures were used to prepare cuttings based on Davies et al. (2018). All cuttings were dipped in rooting hormone $(1000 \mathrm{ppm}$ indole-3-butyric acid +500 ppm napthaleneacetic acid; Dip'N Grow, Clackamas, OR) for $3 \mathrm{~s}$ and a single cutting was inserted into each container (2.5inch diameter, SVD250; T.O. Plastics, Clearwater, MN) filled with a $100 \%$ pine bark substrate amended with 6 $\mathrm{lb} /$ yard $^{3} 18 \mathrm{~N}-2.6 \mathrm{P}-6.6 \mathrm{~K}$ controlledrelease fertilizer (Nutricote 18-6-8 Total Type 180; Florikan Corp., Sarasota, FL), $1 \mathrm{lb} /$ yard $^{3}$ micronutrient fertilizer (Micromax; ICL Specialty Fertilizers, Dublin, $\mathrm{OH}$ ), and $0.5 \mathrm{lb} /$ yard $^{3}$ wetting agent (AquaGro 2000G; Aquatrols, Paulsboro, NJ). Mulches included coarse vermiculite (\#2A; Thermo-O-Rock, New Eagle, PA), rice hulls (Riceland Foods, Stuttgart, $\mathrm{AR}$ ), paper pellets (MPP, Wolcott, NY), and pine pellets (Tractor Supply Co., Brentwood, IN). A non-treated control (nonmulched containers) was also included and consisted of containers filled with pine bark substrate. Coarse vermiculite and rice hulls were selected due to current widespread use as a substrate component (vermiculite) or mulch in container-grown nursery crop production (rice hulls), and paper and pine pellets were selected due to uniform small particle size and widespread availability. Mulches were applied (before sticking cuttings) at two depths ( 0.5 and 1 inch) level with the top of the container. Pine and paper pellets expand after exposure to water, thus pellets were applied at a sufficient thickness to achieve a final depth of 0.5 or 1 inch to the top of the container following saturation. After containers and mulches had been saturated, cuttings were stuck (single cutting per container; 25 cuttings per treatment), completely randomized (within plant species), and placed in a shade house (50\% shade) under intermittent mist (10 s every $8 \mathrm{~min}$ from 6:00 AM to 9:00 PM). The study was ended when sufficient rooting had occurred for the nontreated control of each crop species. Rooted cuttings were harvested on 16 July ('Phantom' hydrangea), 29 July ('Nanho Blue' butterfly bush), and 8 Sept. ('Catawba' crape myrtle), roots were washed and rooting percentage, root dry weight, and shoot dry weight ('Catawba' crape myrtle and 'Nanho Blue' butterfly bush only) were measured. Digital root analysis (total root length and root volume) of 'Catawba' crape myrtle and 'Phantom' hydrangea was completed using WinRHIZO software (Reagent Instruments, Quebec, Canada).

WeEd CONTROL EFFICACY. In a separate study, four weed species were evaluated and included creeping woodsorrel (Oxalis corniculata), hairy bittercress (Cardamine hirsuta), large crabgrass (Digitaria sanguinalis), and mulberry weed (Fatoua villosa). Container substrate and mulches were prepared as described for Rooting and weed seed was applied to the mulch surface. Weed seeds were surfaceapplied to simulate infestation from neighboring containers or weeds in surrounding areas. Although container substrates can become infested with weed seeds before use if not stored properly, substrates used for propagation are typically weed free. A separate set of containers was used for each weed species and 20 (creeping woodsorrel, hairy bittercress, mulberry weed) or 30 (large crabgrass) seeds were sown (28 Feb.) per container (eight replicates per treatment). Containers were completely randomized (within species) and placed in a greenhouse (covered with polyethylene plastic) under intermittent mist (as described earlier). Weed seed germination (percent) was recorded at 
2,4 , and 6 weeks after sowing (WAS). At 7 WAS, shoot fresh weight was collected for all weed species.

MulCH GERMinATION BIOASSAY. Each mulch was mixed with deionized water (500 mL mulch:200 mL water) and allowed to saturate for $24 \mathrm{~h}$ before filtering the solution through a standard coffee filter (white, 8-12 c; Great Value, Bentonville, AR). Two filter paper circles $(90 \mathrm{~mm}$, Whatman 598; GE Healthcare, Amersham, UK) were saturated in the filtrate then placed in a petri dish $(100 \times 15 \mathrm{~mm}$; VWR International, Radnor, PA). Seeds (20 per dish) of two bioindicator species [lettuce (Lactuca sativa) and tomato (Solanum lycopersicum)] were sown in separate dishes (three replicates/mulch/species), lids were replaced, and dishes were sealed with parafilm. All dishes were placed in a growth chamber $\left(26 / 20^{\circ} \mathrm{C}\right.$ day/ night temperature, $14 \mathrm{~h}$ photoperiod) for 2 weeks then seed germination was recorded.

Rooting percentage and weed seed germination data were analyzed with generalized linear models using the binary distribution and a logit link function using the GLIMMIX procedure of SAS (ver. 9.3; SAS Institute, Cary, NC). All other data were analyzed with linear models using the GLIMMIX procedure of SAS and differences between treatment means were determined using the Shaffer simulated method $(P<0.05)$.

\section{Results and discussion}

Rooting. Neither mulch type nor mulch depth affected rooting percentage of the three species. Rooting percentage for the non-treated control was $75 \%$ ('Nanho Blue' butterfly bush), $100 \%$ ('Catawba' crape myrtle), and $100 \%$ ('Phantom' hydrangea). Average rooting percentage for 0.5 - and 1 -inch mulch depth was, respectively, $58 \%$ and 54\% ('Nanho Blue' butterfly bush), 98\% and $100 \%$ ('Catawba' crape myrtle), and $100 \%$ and 96\% ('Phantom' hydrangea). Although 'Nanho Blue' butterfly bush rooting percentage was $15 \%$ to $35 \%$ lower in the mulched treatments compared with the non-treated control, a high amount of variability within each treatment likely resulted in no statistical differences for 'Nanho Blue' butterfly bush. Other rooting parameters, however, were affected by mulch type/depth but response varied by crop species. Root dry weight of 'Nanho Blue' butterfly bush was similar among treatments (Table 1). 'Nanho Blue' butterfly bush shoot dry weight was reduced by paper pellets at both mulch depths but was similar for all other treatments compared with the non-treated control (Table 2).

Root dry weight of 'Catawba' crape myrtle was similar to the nontreated control for all treatments except paper pellets where root dry weight was lower at both mulch depths (0.5 and 1 inch) (Table 1$)$. Root length and volume of 'Catawba' crape myrtle were similar to the nontreated control for vermiculite at both mulch depths and for pine pellets at 0.5 -inch depth. Root growth (length and volume) of 'Catawba' crape myrtle was lower for all other treatments compared with the non-treated control and both root length and volume were more than $50 \%$ lower in paper pellets (Table 3). 'Catawba' crape myrtle shoot dry weight was similar to the non-treated control for vermiculite at both mulch depths along with rice hulls and pine pellets at 0.5 -inch depth (Table 2). All other treatments had reduced shoot dry weight compared with non-treated control, and it was more than $50 \%$ lower for paper pellets at both mulch depths.

Root dry weight of 'Phantom' hydrangea was similar among all the treatments (Table 1). Root length and volume of 'Phantom' hydrangea was lower in paper pellets at the 1inch depth compared with the nontreated control but was similar to the non-treated control for all the other treatments (Table 3).

Among the mulches used in our study, vermiculite had the least effect on rooting of all three crop species evaluated. Rice hulls did not affect root dry weight but reduced root length and volume of 'Catawba' crape myrtle. Vermiculite is widely used in container substrates for greenhouse-grown crops and improves substrate water and nutrient retention (Robbins, 2018). Parboiled rice hulls have been identified as an alternative substrate component and are an agricultural by-product (Buck and Evans, 2010; Currey et al., 2010; Evans, 2008). Because vermiculite and rice hulls can be used as a substrate component without any negative effect on plant growth, the potential negative impact rice hulls may have on rooting cuttings must be considered when applied as a mulch during propagation.

Pine pellets are composed of compressed sawdust, whereas paper pellets are made of compressed recycled paper. No additional ingredients were listed on the packaging, but other chemicals may be used in the manufacturing process and could have phytotoxic properties. Results from the seed germination bioassay showed pine pellets exhibited phytotoxic properties and inhibited lettuce and tomato germination (data not shown). Lettuce germination was 1.6\% (pine pellets), 78.3\% (paper pellets), and $100 \%$ for all other treatments, whereas tomato germination was also lowest for pine pellets (28.3\%) but more than $93 \%$ for all other treatments. The phytotoxic compounds may have contributed to reduced root development in cuttings with pine pellets but does not explain reduced root growth of 'Catawba' crape myrtle in rice hulls.

Other factors that could affect rooting of cuttings and subsequent shoot growth include mulch depth and physical properties of the mulch. Certain mulches may retain more water and potentially limit water movement or moisture content in the rooting zone. Rice hulls had greater porosity (air space) compared with the other mulches and the pine bark substrate (data not shown), thus varying moisture content along the portion of the stem inserted in the container could have resulted in reduced root initiation and growth. The cuttings were inserted $\approx 2$ inches into the container resulting in $25 \%$ to $50 \%$ of the inserted portion of the stem in contact with mulch depending on mulch depth. Mulch depth also offsets the volume of pine bark substrate by up to $30 \%$ (1-inch mulch depth), which could have reduced the amount of nutrients available for root and shoot growth, but substrate nutrient content was not measured.

Weed control efficacy. Germination percentage for creeping woodsorrel at 2 WAS was lower for all mulch treatments compared with the non-treated control (Table 4). At 6 WAS, rice hulls at both depths and pine pellets and paper pellets at 0.5 inch depth reduced germination of creeping woodsorrel by more than $46 \%$ whereas pine pellets at 1 -inch depth reduced germination by $74 \%$. Creeping woodsorrel shoot fresh 
Table 1. Root dry weight of three ornamental crop species treated with four mulches at two depths [0.5 and 1 inch $(1.27$ and $2.54 \mathrm{~cm})]$.

\begin{tabular}{lcccc}
\hline & $\begin{array}{c}\text { Mulch } \\
\text { depth } \\
\text { (inch) }\end{array}$ & $\begin{array}{c}\text { 'Nanho Blue' } \\
\text { butterfly bush }\end{array}$ & $\begin{array}{c}\text { 'Catawba' } \\
\text { crape myrtle }\end{array}$ & $\begin{array}{c}\text { 'Phantom' } \\
\text { hydrangea }\end{array}$ \\
\cline { 4 - 6 } Treatment $^{\mathrm{z}}$ & None & 0.19 & $0.23 \mathrm{ab}^{\mathrm{x}}$ & 0.16 \\
\hline Non-treated control & & 0.10 & $0.26 \mathrm{a}$ & 0.17 \\
\hline Vermiculite & 0.5 & 0.17 & $0.12 \mathrm{bc}$ & 0.12 \\
Rice hulls & & 0.11 & $0.19 \mathrm{abc}$ & 0.16 \\
Pine pellets & & 0.05 & $0.10 \mathrm{c}$ & 0.17 \\
Paper pellets & & 0.10 & $0.19 \mathrm{abc}$ & 0.18 \\
Vermiculite & 1 & 0.14 & $0.13 \mathrm{bc}$ & 0.14 \\
Rice hulls & & 0.12 & $0.13 \mathrm{bc}$ & 0.17 \\
Pine pellets & & 0.11 & $0.10 \mathrm{c}$ & 0.11 \\
Paper pellets & & 1.62 & 5.67 & 1.79 \\
\hline$F$ & & 0.1231 & $<0.0001$ & 0.0825 \\
$P$ & & &
\end{tabular}

${ }^{\mathrm{z}}$ Mulches applied before sticking of cuttings (single cutting per container). Containers $[2.5$ inches $(6.35 \mathrm{~cm})$ diameter] filled with a $100 \%$ pine bark substrate amended with $6 \mathrm{lb} /$ yard $^{3} 18 \mathrm{~N}-2.6 \mathrm{P}-6.6 \mathrm{~K}$ controlled-release

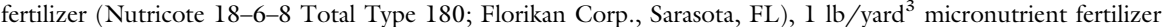
(Micromax; ICL Specialty Fertilizers, Dublin, OH), and $0.5 \mathrm{lb} /$ yard $^{3}$ wetting agent (AquaGro 2000G; Aquatrols, Paulsboro, NJ); $1 \mathrm{lb} / \mathrm{yard}^{3}=0.5933 \mathrm{~kg} \cdot \mathrm{m}^{-3}$.

${ }^{\mathrm{y}} 1 \mathrm{~g}=0.0353 \mathrm{oz}$.

${ }^{\mathrm{x}}$ Means within a column that do not share same letters indicate significant difference at $P<0.05$ based on Shaffer simulated method.

weight was lowest in rice hulls, pine pellets, and paper pellets at both depths (Table 5). Rice hulls at both mulch depths lowered the shoot fresh weight of woodsorrel by more than $90 \%$, whereas no measurable shoot fresh weight was recorded for pine pellets or paper pellets (both depths).

Germination percentage for hairy bittercress at 2 WAS lowest for pine pellets followed by, paper pellets, followed by rice hulls compared with the non-treated control at both mulch depths (Table 4). Rice hulls reduced hairy bittercress germination by more than $25 \%$, whereas pine pellets and paper pellets reduced germination by more than $59 \%$ at both mulch depths compared with the non-treated control. By 4 WAS, pine pellets $(0.5$ and $l$ inch) were the most effective treatments and reduced hairy bittercress germination by more than $41 \%$ in comparison with the non-treated

Table 2. Shoot dry weight of two ornamental crop species treated with four mulches at two depths [0.5 and 1 inch $(1.27$ and $2.54 \mathrm{~cm})]$.

\begin{tabular}{|c|c|c|c|}
\hline \multirow[b]{2}{*}{ Treatment $^{\mathrm{z}}$} & \multirow{2}{*}{$\begin{array}{l}\text { Mulch depth } \\
\text { (inch) }\end{array}$} & $\begin{array}{l}\text { 'Nanho Blue' } \\
\text { butterfly bush }\end{array}$ & $\begin{array}{c}\text { 'Catawba' } \\
\text { crape myrtle } \\
\end{array}$ \\
\hline & & \multicolumn{2}{|c|}{ Shoot dry wt $(\mathrm{g})^{\mathrm{y}}$} \\
\hline Non-treated control & None & $0.81 \mathrm{a}^{\mathrm{x}}$ & $1.26 \mathrm{a}$ \\
\hline $\begin{array}{l}\text { Vermiculite } \\
\text { Rice hulls } \\
\text { Pine pellets } \\
\text { Paper pellets }\end{array}$ & 0.5 & $\begin{array}{l}0.34 \mathrm{ab} \\
0.55 \mathrm{ab} \\
0.41 \mathrm{ab} \\
0.17 \mathrm{~b}\end{array}$ & $\begin{array}{l}1.36 \mathrm{a} \\
0.83 \mathrm{abc} \\
0.95 \mathrm{abc} \\
0.55 \mathrm{bc}\end{array}$ \\
\hline $\begin{array}{l}\text { Vermiculite } \\
\text { Rice hulls } \\
\text { Pine pellets } \\
\text { Paper pellets }\end{array}$ & 1 & $\begin{array}{l}0.33 \mathrm{ab} \\
0.52 \mathrm{ab} \\
0.33 \mathrm{ab} \\
0.23 \mathrm{~b}\end{array}$ & $\begin{array}{l}1.06 \mathrm{ab} \\
0.68 \mathrm{bc} \\
0.68 \mathrm{bc} \\
0.47 \mathrm{c}\end{array}$ \\
\hline $\begin{array}{l}F \\
P\end{array}$ & & $\begin{array}{l}2.66 \\
0.0089\end{array}$ & $\begin{aligned} & 6.22 \\
< & 0.0001\end{aligned}$ \\
\hline \multicolumn{4}{|c|}{$\begin{array}{l}{ }^{7} \text { Mulches applied before sticking of cuttings (single cutting per container). Containers [2.5 inches }(6.35 \mathrm{~cm}) \\
\text { diameter] filled with a } 100 \% \text { pine bark substrate amended with } 6 \mathrm{lb} / \mathrm{yard}^{3} 18 \mathrm{~N}-2.6 \mathrm{P}-6.6 \mathrm{~K} \text { controlled-release } \\
\text { fertilizer (Nutricote } 18-6-8 \text { Total Type } 180 \text {; Florikan Corp., Sarasota, FL), } 1 \mathrm{lb} / \text { yard }{ }^{3} \text { micronutrient fertilizer } \\
\text { (Micromax; ICL Specialty Fertilizers, Dublin, OH), and } 0.5 \mathrm{lb} / \mathrm{yard}^{3} \text { wetting agent (AquaGro } 2000 \mathrm{G} \text {; Aqua- } \\
\text { trols, Paulsboro, NJ); } 1 \mathrm{lb} / \mathrm{yard}^{3}=0.5933 \mathrm{~kg} \cdot \mathrm{m}^{-3} \text {. } \\
{ }^{\mathrm{y}} 1 \mathrm{~g}=0.0353 \mathrm{oz} .\end{array}$} \\
\hline
\end{tabular}

control. At 6 WAS, hairy bittercress germination was lowest for pine pellets at the 0.5 -inch $(3.8 \%)$ and 1 inch $(0.0 \%)$ depths. Hairy bittercress shoot fresh weight was lowest in pine pellets and paper pellets at both mulch depths (Table 5).

Germination percentage of large crabgrass at 2 WAS was lowest for rice hulls at 0.5 inch, pine pellets at both depths, and paper pellets at 1 inch (Table 6). By 4 WAS, only pine pellets (1 inch) reduced percent germination of large crabgrass (by 22\%) compared with the non-treated control. At 6 WAS, germination was similar among all the treatments. Large crabgrass shoot fresh weight was lower for all the treatments compared with the non-treated control except vermiculite (0.5 inch) (Table 5$)$. Pine pellets at both mulch depths lowered the shoot fresh weight of large crabgrass by more than $99 \%$. Paper pellets at 0.5 - and 1inch depth lowered the shoot fresh weight by $99 \%$ and $100 \%$, respectively.

At 2 WAS, mulberry weed germination percentage was similar or greater for all mulches compared with the non-treated control (Table 6). At 4 WAS, mulberry weed germination was lower for rice hulls $(0.5$ and 1 inch) and paper pellets compared with the non-treated control. At 6 WAS, rice hulls at both mulch depths and paper pellets at 1 -inch depth lowered the germination by more than $24 \%$. Mulberry weed shoot fresh weight was lowest in pine pellets and paper pellets at both mulch depths and was reduced more than $92 \%$ compared with the non-treated control (Table 5).

Weed seed germination in the non-treated control varied by species and ranged $58 \%$ to $98 \%$. A screened pine bark was used as the rooting substrate, but many growers use peatbased substrates for propagation which have smaller particles size and would likely result in similar or greater weed seed germination. Weed control efficacy can vary depending on the type of mulch used and application depth. In agreement with our results, weed control efficacy of loose-fill mulches generally increased with an increase in the application depth (Cochran et al., 2009; Knox et al., 2015; Penny and Neal, 2003; Smith et al., 1997). Mulch applied at adequate depths, generally 1 inch or greater, has provided better control of common nursery and landscape 
Table 3. Total root length and root volume of two ornamental crop species treated with four mulches at two depths [0.5 and 1 inch $(1.27$ and $2.54 \mathrm{~cm})]$.

\begin{tabular}{|c|c|c|c|c|c|}
\hline \multirow{2}{*}{$\frac{\text { Treatment }^{\mathrm{z}}}{\text { Non-treated control }}$} & \multirow{2}{*}{$\begin{array}{c}\begin{array}{c}\text { Mulch depth } \\
\text { (inch) }\end{array} \\
\text { None } \\
\end{array}$} & $\begin{array}{c}\text { 'Catawba' crape } \\
\text { myrtle }\end{array}$ & $\begin{array}{l}\text { 'Phantom' } \\
\text { hydrangea }\end{array}$ & $\begin{array}{c}\text { 'Catawba' crape } \\
\text { myrtle }\end{array}$ & $\begin{array}{l}\text { 'Phantom' } \\
\text { hydrangea }\end{array}$ \\
\hline & & \multicolumn{2}{|c|}{ Root length $(\mathrm{cm})^{\mathrm{y}}$} & \multicolumn{2}{|c|}{ Root vol $\left(\mathrm{cm}^{3}\right)^{\mathrm{y}}$} \\
\hline $\begin{array}{l}\text { Vermiculite } \\
\text { Rice hulls } \\
\text { Pine pellets } \\
\text { Paper pellets } \\
\end{array}$ & 0.5 & $\begin{array}{l}749.6 \mathrm{a} \\
492.5 \mathrm{bc} \\
563.9 \mathrm{abc} \\
374.4 \mathrm{c} \\
\end{array}$ & $\begin{array}{l}847.6 \mathrm{a} \\
615.7 \mathrm{ab} \\
762.48 \mathrm{ab} \\
780.9 \mathrm{ab} \\
\end{array}$ & $\begin{array}{l}1.39 \mathrm{a} \\
0.82 \mathrm{bcd} \\
1.05 \mathrm{abc} \\
0.55 \mathrm{~cd}\end{array}$ & $\begin{array}{l}2.06 \mathrm{a} \\
1.41 \mathrm{ab} \\
1.77 \mathrm{ab} \\
1.66 \mathrm{ab}\end{array}$ \\
\hline $\begin{array}{l}\text { Vermiculite } \\
\text { Rice hulls } \\
\text { Pine pellets } \\
\text { Paper pellets }\end{array}$ & 1 & $\begin{array}{l}621.6 \mathrm{abc} \\
416.1 \mathrm{bc} \\
424.7 \mathrm{bc} \\
347.9 \mathrm{c}\end{array}$ & $\begin{array}{l}872.6 \mathrm{a} \\
608.8 \mathrm{ab} \\
793.2 \mathrm{ab} \\
504.3 \mathrm{~b} \\
\end{array}$ & $\begin{array}{l}1.10 \mathrm{ab} \\
0.77 \mathrm{bcd} \\
0.79 \mathrm{bcd} \\
0.50 \mathrm{~d}\end{array}$ & $\begin{array}{l}2.11 \mathrm{a} \\
1.43 \mathrm{ab} \\
1.79 \mathrm{ab} \\
1.07 \mathrm{~b} \\
\end{array}$ \\
\hline $\begin{array}{l}F \\
P\end{array}$ & & $\begin{array}{c}8.51 \\
<0.0001\end{array}$ & $\begin{array}{l}2.72 \\
0.0076\end{array}$ & $\begin{array}{c}7.62 \\
<0.0001\end{array}$ & $\begin{array}{l}3.74 \\
0.0005\end{array}$ \\
\hline
\end{tabular}

${ }^{\mathrm{z}}$ Mulches applied before sticking of cuttings (single cutting per container). Containers [2.5 inches $(6.35 \mathrm{~cm})$ diameter] filled with a $100 \%$ pine bark substrate amended with $6 \mathrm{lb} /$ yard $^{3} 18 \mathrm{~N}-2.6 \mathrm{P}-6.6 \mathrm{~K}$ controlled-release fertilizer (Nutricote 18-6-8 Total Type 180; Florikan Corp., Sarasota, FL), l lb/yard ${ }^{3}$ micronutrient fertilizer (Micromax; ICL Specialty Fertilizers, Dublin, OH), and $0.5 \mathrm{lb} /$ yard $^{3}$ wetting agent (AquaGro $2000 \mathrm{G} ;$ Aquatrols, Paulsboro, $\mathrm{NJ}$ ); $1 \mathrm{lb} /$ yard ${ }^{3}=0.5933 \mathrm{~kg} \cdot \mathrm{m}^{-3}$.

${ }^{\mathrm{y}} 1 \mathrm{~cm}=0.3937$ inch, $1 \mathrm{~cm}^{3}=0.0610$ inch $^{3}$.

${ }^{\mathrm{x}}$ Means within a column that do not share same letters indicate significant difference at $P<0.05$ based on Shaffer simulated method.

weed species compared with preemergence herbicides (Bartley et al., 2017; Burrows, 2017; Marble et al., 2017; Saha et al., 2019). In our study, pine pellets and paper pellets at $0.5-$ and l-inch depth resulted in minimal growth of four weed species (creeping woodsorrel, hairy bittercress, large crabgrass, mulberry weed). Although weed seeds germinated on the surface of pine and paper pellets and were still alive at 6 WAS, seedlings only

developed two true leaves and did not accumulate a measurable amount of shoot biomass.

Pine pellets and paper pellets provided a solid compact barrier which may have inhibited the weed seedling roots from penetrating the substrate surface and accessing nutrients within, thus limiting shoot growth. In a study by Smith et al. (1998), recycled wastepaper pellets applied to a depth of 1 inch completely suppressed prostrate spurge germination

Table 4. Percent germination [2, 4, and 6 weeks after sowing (WAS)] of creeping woodsorrel and hairy bittercress seeds sown to four mulches at two depths [0.5 and 1 inch $(1.27$ and $2.54 \mathrm{~cm})]$.

\begin{tabular}{|c|c|c|c|c|c|c|c|}
\hline \multirow[b]{3}{*}{ Treatment $^{\mathrm{z}}$} & \multirow{3}{*}{$\begin{array}{l}\text { Mulch } \\
\text { depth } \\
\text { (inch) }\end{array}$} & \multicolumn{3}{|c|}{ Creeping woodsorrel } & \multicolumn{3}{|c|}{ Hairy bittercress } \\
\hline & & \multicolumn{6}{|c|}{ Germination (\%) } \\
\hline & & 2 WAS & 4 WAS & 6 WAS & 2 WAS & 4 WAS & 6 WAS \\
\hline $\begin{array}{l}\text { Non-treated } \\
\text { control }\end{array}$ & None & $44.4 \mathrm{a}^{\mathrm{y}}$ & $86.3 \mathrm{a}$ & $77.5 \mathrm{ab}$ & 82.5 a & $96.3 \mathrm{a}$ & $90.0 \mathrm{a}$ \\
\hline $\begin{array}{l}\text { Vermiculite } \\
\text { Rice hulls } \\
\text { Pine pellets } \\
\text { Paper pellets }\end{array}$ & 0.5 & $\begin{array}{r}14.4 \mathrm{~b} \\
1.3 \mathrm{~b} \\
0.0 \mathrm{~b} \\
5.0 \mathrm{~b}\end{array}$ & $\begin{array}{l}78.1 \mathrm{a} \\
23.8 \mathrm{~cd} \\
46.3 \mathrm{bc} \\
44.4 \mathrm{bc}\end{array}$ & $\begin{array}{l}87.5 \mathrm{a} \\
21.3 \mathrm{~cd} \\
26.9 \mathrm{~cd} \\
30.6 \mathrm{c}\end{array}$ & $\begin{array}{l}91.3 \mathrm{a} \\
49.4 \mathrm{~b} \\
10.0 \mathrm{~cd} \\
18.1 \mathrm{c}\end{array}$ & $\begin{array}{l}93.8 \mathrm{a} \\
89.4 \mathrm{a} \\
54.4 \mathrm{~b} \\
85.6 \mathrm{a}\end{array}$ & $\begin{array}{r}88.8 \mathrm{a} \\
83.8 \mathrm{a} \\
3.8 \mathrm{~b} \\
95.0 \mathrm{a}\end{array}$ \\
\hline $\begin{array}{l}\text { Vermiculite } \\
\text { Rice hulls } \\
\text { Pine pellets } \\
\text { Paper pellets } \\
\end{array}$ & 1 & $\begin{array}{l}6.9 \mathrm{~b} \\
5.6 \mathrm{~b} \\
0.0 \mathrm{~b} \\
3.8 \mathrm{~b} \\
\end{array}$ & $\begin{array}{l}90.6 \mathrm{a} \\
27.5 \mathrm{bcd} \\
16.3 \mathrm{~d} \\
49.4 \mathrm{~b} \\
\end{array}$ & $\begin{array}{l}83.8 \mathrm{a} \\
18.8 \mathrm{~cd} \\
3.1 \mathrm{~d} \\
56.9 \mathrm{~b} \\
\end{array}$ & $\begin{array}{r}95.6 \mathrm{a} \\
56.9 \mathrm{~b} \\
1.3 \mathrm{~d} \\
23.1 \mathrm{c}\end{array}$ & $\begin{array}{l}92.5 \mathrm{a} \\
86.9 \mathrm{a} \\
52.5 \mathrm{~b} \\
81.9 \mathrm{a}\end{array}$ & $\begin{array}{r}93.8 \mathrm{a} \\
85.6 \mathrm{a} \\
0.0 \mathrm{~b} \\
88.1 \mathrm{a} \\
\end{array}$ \\
\hline $\begin{array}{l}F \\
P\end{array}$ & & $\begin{array}{l}17.61 \\
<0.0001\end{array}$ & $\begin{array}{l}20.94 \\
<0.0001\end{array}$ & $\begin{array}{l}26.23 \\
<0.0001\end{array}$ & $\begin{array}{l}76.31 \\
<0.0001\end{array}$ & $\begin{array}{c}8.46 \\
<0.0001\end{array}$ & $\begin{array}{l}104.65 \\
<0.0001\end{array}$ \\
\hline
\end{tabular}

${ }^{\mathrm{z}}$ Mulches applied before sticking of cuttings (single cutting per container). Containers $[2.5$ inches $(6.35 \mathrm{~cm})$ diameter] filled with a $100 \%$ pine bark substrate amended with $6 \mathrm{lb} / \mathrm{yard}^{3} 18 \mathrm{~N}-2.6 \mathrm{P}-6.6 \mathrm{~K}$ controlled-release fertilizer (Nutricote 18-6-8 Total Type 180; Florikan Corp., Sarasota, FL), 1 lb/yard ${ }^{3}$ micronutrient fertilizer (Micromax; ICL Specialty Fertilizers, Dublin, OH), and $0.5 \mathrm{lb} /$ yard $^{3}$ wetting agent (AquaGro 2000G; Aquatrols, Paulsboro, NJ); $1 \mathrm{lb} /$ yard $^{3}=0.5933 \mathrm{~kg} \cdot \mathrm{m}^{-3}$.

${ }^{\mathrm{y}}$ Means within a column that do not share same letters indicate significant difference at $P<0.05$ based on Shaffer simulated method. in container production. In a study by Altland (2019), rice hulls at 0.5 - or 1inch depth provided $100 \%$ control of bittercress and liverwort growth in containers. Similarly, Altland et al. (2016) reported parboiled rice hulls provided effective control of creeping woodsorrel and flexuous bittercress when applied at 0.5 to 1 -inch depth over the container substrate surface. In our study, rice hulls reduced shoot weight of creeping woodsorrel and large crabgrass but were not effective on hairy bittercress or mulberry weed. Although rice hulls work well in controlling weeds in container production, the frequent irrigation and high moisture environment of propagation negated the hydrophobic properties of rice hulls and provided adequate conditions for weed seed germination and shoot fresh weight. Vermiculite was also not effective at suppressing weed shoot weight likely due to increased moisture content of the mulch layer and ineffective surface barrier.

Low fertility, large particle size, and hydrophobic nature are desirable properties of mulches for containergrown crops but may not have the same impact or be practical in the propagation environment. We demonstrated mulch products with small particle size (paper and pine pellets) provided excellent weed control efficacy (percent control of the non-treated control) for creeping woodsorrel $(100 \%)$, hairy bittercress $(98 \%$ to $100 \%)$, large crabgrass (96\% to $100 \%)$, and mulberry weed $(100 \%)$ during cutting propagation. 
Table 5. Shoot fresh weight ( 7 weeks after sowing) of four weed species (creeping woodsorrel, hairy bittercress, large crabgrass, mulberry weed) from seeds sown to four mulches at two depths [0.5 and 1 inch $(1.27$ and $2.54 \mathrm{~cm})]$.

\begin{tabular}{lccccc}
\hline & $\begin{array}{c}\text { Mulch } \\
\text { depth } \\
\text { (inch) }\end{array}$ & $\begin{array}{c}\text { Creeping } \\
\text { woodsorrel }\end{array}$ & $\begin{array}{c}\text { Hairy } \\
\text { bittercress }\end{array}$ & $\begin{array}{c}\text { Large } \\
\text { crabgrass }\end{array}$ & $\begin{array}{c}\text { Mulberry } \\
\text { weed }\end{array}$ \\
\cline { 4 - 7 } Nreatment & & Shoot fresh wt $(\mathbf{g})^{\mathbf{y}}$ & \\
\hline Non-treated control & None & $1.04 \mathrm{a}^{\mathrm{x}}$ & $0.97 \mathrm{ab}$ & $4.39 \mathrm{a}$ & $0.13 \mathrm{ab}$ \\
\hline Vermiculite & & $0.79 \mathrm{ab}$ & $0.95 \mathrm{ab}$ & $3.12 \mathrm{ab}$ & $0.16 \mathrm{a}$ \\
Rice hulls & 0.5 & $0.09 \mathrm{bc}$ & $0.97 \mathrm{ab}$ & $2.89 \mathrm{~b}$ & $0.09 \mathrm{ab}$ \\
Pine pellets & & $0.00 \mathrm{c}$ & $0.02 \mathrm{c}$ & $0.17 \mathrm{c}$ & $0.01 \mathrm{c}$ \\
Paper pellets & & $0.00 \mathrm{c}$ & $0.00 \mathrm{c}$ & $0.02 \mathrm{c}$ & $0.00 \mathrm{c}$ \\
\hline Vermiculite & & $0.92 \mathrm{a}$ & $1.15 \mathrm{a}$ & $2.34 \mathrm{~b}$ & $0.11 \mathrm{ab}$ \\
Rice hulls & 1 & $0.02 \mathrm{c}$ & $0.27 \mathrm{bc}$ & $2.65 \mathrm{~b}$ & $0.06 \mathrm{bc}$ \\
Pine pellets & & $0.00 \mathrm{c}$ & $0.00 \mathrm{c}$ & $0.03 \mathrm{c}$ & $0.00 \mathrm{c}$ \\
Paper pellets & & $0.00 \mathrm{c}$ & $0.00 \mathrm{c}$ & $0.00 \mathrm{c}$ & $0.00 \mathrm{c}$ \\
\hline$F$ & & 6.80 & 8.58 & 27.21 & 13.08 \\
$P$ & & $<0.0001$ & $<0.0001$ & $<0.0001$ & $<0.0001$ \\
\hline
\end{tabular}

${ }^{\mathrm{z}}$ Mulches were applied to containers before sowing weed seeds [20 (creeping woodsorrel, hairy bittercress, and mulberry weed) or 30 (large crabgrass) seeds per container]. Containers [2.5 inches $(6.35 \mathrm{~cm})$ diameter] filled with a $100 \%$ pine bark substrate amended with $6 \mathrm{lb} /$ yard $^{3} 18 \mathrm{~N}-2.6 \mathrm{P}-6.6 \mathrm{~K}$ controlled-release fertilizer (Nutricote 18-6-8 Total Type 180; Florikan Corp., Sarasota, FL), 1 lb/yard ${ }^{3}$ micronutrient fertilizer (Micromax; ICL Specialty Fertilizers, Dublin, OH), and $0.5 \mathrm{lb} / \mathrm{yard}^{3}$ wetting agent (AquaGro 2000G; Aquatrols, Paulsboro, $\mathrm{NJ}) ; 1 \mathrm{lb} / \mathrm{yard}^{3}=0.5933 \mathrm{~kg} \cdot \mathrm{m}^{-3}$

${ }^{\mathrm{y}} 1 \mathrm{~g}=0.0353 \mathrm{oz}$.

${ }^{x}$ Means within a column that do not share same letters indicate significant difference at $P<0.05$ based on Shaffer simulated method.

Nevertheless, paper and pine pellets may reduce cutting root growth of certain crop species when applied at a depth greater than 0.5 inch. Paper and pine pellets applied at 0.5 -inch depth would be a viable option for crops propagated in greenhouses and on

crop species that are known to be herbicide sensitive such as 'Phantom' hydrangea. Longevity of weed control efficacy has not been widely studied, but preliminary trials conducted by the authors (data not shown) indicate mulches would be effective on hairy

Table 6. Percent germination [ 2,4 , and 6 weeks after sowing (WAS)] of large crabgrass and mulberry weed seeds sown to four mulches at two depths $[0.5$ and 1 inch $(1.27$ and $2.54 \mathrm{~cm})]$.

\begin{tabular}{|c|c|c|c|c|c|c|c|}
\hline \multirow[b]{3}{*}{ Treatment $^{\mathrm{z}}$} & \multirow{3}{*}{$\begin{array}{l}\text { Mulch } \\
\text { depth } \\
\text { (inch) }\end{array}$} & \multicolumn{3}{|c|}{ Large crabgrass } & \multicolumn{3}{|c|}{ Mulberry weed } \\
\hline & & \multicolumn{6}{|c|}{ Germination (\%) } \\
\hline & & 2 WAS & 4 WAS & 6 WAS & 2 WAS & 4 WAS & 6 WAS \\
\hline $\begin{array}{c}\text { Non-treated } \\
\text { control }\end{array}$ & None & $37.5 \mathrm{~b}^{\mathrm{y}}$ & $55.8 \mathrm{ab}$ & $58.8 \mathrm{abc}$ & $24.4 \mathrm{c}$ & $98.1 \mathrm{a}$ & $98.1 \mathrm{a}$ \\
\hline $\begin{array}{l}\text { Vermiculite } \\
\text { Rice hulls } \\
\text { Pine pellets } \\
\text { Paper pellets }\end{array}$ & 0.5 & $\begin{array}{l}56.7 \mathrm{a} \\
15.4 \mathrm{~cd} \\
12.9 \mathrm{~cd} \\
26.3 \mathrm{bcd}\end{array}$ & $\begin{array}{l}64.6 \mathrm{a} \\
51.7 \mathrm{abc} \\
49.6 \mathrm{abc} \\
49.2 \mathrm{abc}\end{array}$ & $\begin{array}{l}65.4 \mathrm{ab} \\
51.7 \mathrm{abc} \\
51.7 \mathrm{abc} \\
49.6 \mathrm{bc}\end{array}$ & $\begin{array}{r}57.5 \mathrm{~b} \\
6.3 \mathrm{c} \\
10.6 \mathrm{c} \\
13.1 \mathrm{c}\end{array}$ & $\begin{array}{l}95.6 \mathrm{ab} \\
65.0 \mathrm{~cd} \\
81.3 \mathrm{abcd} \\
85.6 \mathrm{abc}\end{array}$ & $\begin{array}{l}96.9 \mathrm{ab} \\
73.8 \mathrm{bc} \\
84.4 \mathrm{abc} \\
86.9 \mathrm{abc}\end{array}$ \\
\hline $\begin{array}{l}\text { Vermiculite } \\
\text { Rice hulls } \\
\text { Pine pellets } \\
\text { Paper pellets }\end{array}$ & 1 & $\begin{array}{l}58.8 \mathrm{a} \\
31.3 \mathrm{bc} \\
10.4 \mathrm{~d} \\
13.8 \mathrm{~cd}\end{array}$ & $\begin{array}{l}65.8 \mathrm{a} \\
52.9 \mathrm{ab} \\
33.8 \mathrm{c} \\
45.0 \mathrm{bc}\end{array}$ & $\begin{array}{l}68.8 \mathrm{a} \\
48.8 \mathrm{bc} \\
42.5 \mathrm{c} \\
46.3 \mathrm{c}\end{array}$ & $\begin{array}{r}83.1 \mathrm{a} \\
0.6 \mathrm{c} \\
0.6 \mathrm{c} \\
11.9 \mathrm{c}\end{array}$ & $\begin{array}{l}96.9 \mathrm{ab} \\
58.8 \mathrm{~d} \\
78.1 \mathrm{abcd} \\
72.5 \mathrm{bcd}\end{array}$ & $\begin{array}{l}97.5 \mathrm{ab} \\
67.5 \mathrm{c} \\
91.3 \mathrm{abc} \\
72.5 \mathrm{c}\end{array}$ \\
\hline $\begin{array}{l}F \\
P \\
\end{array}$ & & $\begin{array}{l}17.75 \\
<0.0001\end{array}$ & $\begin{aligned} & 5.53 \\
&< 0.0001 \\
&\end{aligned}$ & $\begin{aligned} & 5.10 \\
&< 0.0001 \\
&\end{aligned}$ & $\begin{array}{l}23.72 \\
<0.0001\end{array}$ & $\begin{aligned} & 6.48 \\
&< 0.0001 \\
&\end{aligned}$ & $\begin{array}{l}4.82 \\
0.0001 \\
\end{array}$ \\
\hline \multicolumn{8}{|c|}{ 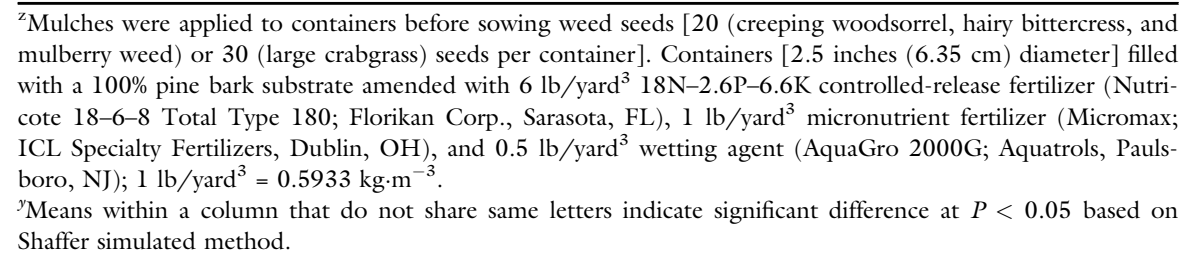 } \\
\hline
\end{tabular}

bittercress and large crabgrass for 8 to 10 weeks. These products are readily available, but nursery propagators would need to determine the costeffectiveness of using mulches compared with the labor and time associated with hand weeding. Growers would also need to alter practices such as filling flats/containers to accommodate the top mulch layer. Some plant species may be more sensitive to differences in chemical and physical properties in the rooting zone, therefore growers should conduct small trials with individual crop species before large scale adoption.

\section{Literature cited}

Abbey, T.M., T.L. Mervosh, A.F. Senesac, and I.T. Bradley. 2001. Mulches for weed suppression in containers of herbaceous perennials. Perennial Plant Assn. Qrtly. J. 9(Autumn):24.

Altland, J. 2019. USDA tests PBH rice hulls for weed control in container crops. 2 July 2021. <https://www.nurserymag. $\mathrm{com} /$ article/usda-tests-rice-hulls-weedcontrol-container-crops $>$.

Altland, J. and C. Krause. 2014. Parboiled rice hull mulch in containers reduces liverwort and flexuous bittercress growth. J. Environ. Hort. 32:59-63, https://doi.org/ 10.24266/0738-2898.32.2.59.

Altland, J.E., C.H. Gilliam, and G. Wehtje. 2003. Weed control in field nurseries. HortTechnology 13:9-14, https:// doi.org/10.21273/HORTTECH.13.1. 0009.

Altland, J.E., J.K. Boldt, and C.C. Krause. 2016. Rice hull mulch affects germination of bittercress and creeping woodsorrel in container plant culture. Amer. J. Plant Sci. 7:2359-2375, https://doi.org/10.4236/ ajps.2016.716207.

Bartley, P.C., G.R. Wehtje, A.M. Murphy, W.G. Foshee, and C.H. Gilliam. 2017. Mulch type and depth influences control of three major weed species in nursery container production. HortTechnology 27:465-471, https://doi.org/10.21273/ HORTTECH03511-16.

Buck, J.S. and M.R. Evans. 2010. Physical properties of ground parboiled fresh rice hulls used as a horticultural substrate. HortScience 45:643-649, https://doi.org/ 10.21273/HORTSCI.45.4.643.

Burrows, M. 2017. Evaluation of pine bark mulch-herbicide combinations for weed control in nursery containers. Master's thesis, Auburn Univ., Auburn, AL. 
Charlton, D. and J.E. Taylor. 2016. A declining farm workforce: Analysis of panel data from rural Mexico. Amer. J. Agr. Econ. 98:1158-1180, https://doi. org/10.1093/ajae/aaw018

Chong, C. 2003. Experiences with weed discs and other nonchemical alternatives for container weed control. HortTechnology 13:23-27, https://doi.org/10.21273/ HORTTECH.13.1.0023.

Cochran, D.R., C.H. Gilliam, D.J. Eakes, G.R. Wehtje, and P.R. Knight. 2008. Herbicide use in propagation of Loropetalum chinense 'Ruby'. J. Environ. Hort. 26:139-143, https://doi.org/10.24266/ 0738-2898-26.3.139.

Cochran, D.R., C.H. Gilliam, D.J. Eakes, G.R. Wehtje, P.R. Knight, and J. Olive. 2009. Mulch depth affects weed germination. J. Environ. Hort. 27:85-90, https:// doi.org/10.24266/0738-2898-27.2.85.

Cook, J.C. and J.C. Neal. 2001. Effects of herbicides and application timing on rooting of azalea and japanese holly cuttings. Proc. Southern Nursery Assoc. Res. Conf. 46:422-424.

Currey, C.J., D.M. Camberato, A.P. Torres, and R.G. Lopez. 2010. Plant growth retardant drench efficacy is not affected by substrate containing parboiled rice hulls. HortTechnology 20:863-866, https:// doi.org/10.21273/HORTTECH.20.5. 863.

Davies, F.T., Jr., R.L. Geneve, and S.B. Wilson. 2018 Hartmann and Kester's plant propagation: Principles and practices. 9th ed. Pearson Educ., New York, NY.

Evans, M. 2008. Rice hulls 101. Grower Talks 71:60.
Ferguson, J., B. Rathinasabapathi, and C. Warren. 2008. Southern red cedar and southern magnolia wood chip mulches for weed suppression in containerized woody ornamentals. HortTechnology 18:266-270, https://doi.org/10.21273/HORTTECH. 18.2.266.

Judge, C.A., J.C. Neal, and J.B. Weber. 2004. Dose and concentration responses of common nursery weeds to Gallery, Surflan and Treflan. J. Environ. Hort. 22:106112, https://doi.org/10.24266/0738-28 98-22.2.106

Knox, G. W., M. Chappell, and R.H. Stamps. 2015. Alternatives to synthetic herbicides for weed management in container nurseries. Univ. Florida Coop. Ext. IFAS ENHI203.

Marble, C. and A. Chandler. 2016. Determining safety of preemergence herbicide use during propagation of three woody ornamental species. 2 July 2021. <http:// www.canr.org/newsletter/Preemergence HerbicideinPropagation.pdf $>$.

Marble, S.C., A.K. Koeser, G. Hasing, D. McClean, and A. Chandler. 2017. Efficacy and estimated annual cost of common weed control methods in landscape planting beds. HortTechnology 27:199-211, https://doi.org/10.21273/HORTTECH 03609-16.

Marble, S.C., S.T. Steed, D. Saha, and Y. Khamare. 2019. On-farm evaluations of wood-derived, waste paper, and plastic mulch materials for weed control in Florida container nurseries. HortTechnology 29:866-873, https://doi.org/10.21273/ HORTTECH04437-19.

Mathers, H. and E. Ozkan. 2001. Herbicide treated mulches. NMPro 17:61-66.
Penny, G.M. and J.C. Neal. 2003. Light, temperature, seed burial, and mulch effects on mulberry weed (Fatoua villosa) seed germination. Weed Technol. 17:213-218, https://doi.org/10.1614/0890-037X (2003)017[0213:LTSBAM]2.0.CO;2.

Robbins, J.A. 2018. Growing media for container production in a greenhouse or nursery - Part I. Components and mixes. Univ. Arkansas Coop. Ext. FSA6097.

Saha, D., S.C. Marble, B.J. Pearson, H.E. Pérez, G.E. MacDonald, and D.C. Odero. 2019. Mulch type and depth, herbicide formulation, and post application irrigation volume influence on control of common landscape weed species. HortTechnology 29:65-77, https://doi.org/ 10.21273/HORTTECH04208-18.

Smith, D.R., C.H. Gilliam, J.H. Edwards, D.J. Eakes, and J.D. Williams. 1997. Recycled wastepaper as a landscape mulch. J. Environ. Hort. 15:191-196, https:// doi.org/10.24266/0738-2898-15.4.191.

Smith, D.R., C.H. Gilliam, J.H. Edwards, J.W. Olive, D.J. Eakes, and J.D. Williams. 1998. Recycled wastepaper as a non-chemical alternative for weed control in container production. J. Environ. Hort. 16:69-75, https://doi.org/10.24266/0738-2898-16. 2.69 .

Thetford, M. and C.H. Gilliam. 1991. Herbicide use in propagation: Effects on rooting and root growth of stem cuttings. J. Environ. Hort. 9:21-23, https://doi. org/10.24266/0738-2898-9.1.21.

Witcher, A.L. and I. Poudel. 2020. Preemergence herbicides and mulches for weed control in cutting propagation. Agronomy 10:1249, https://doi.org/10.3390/agronomy 10091249. 